\title{
Intragastric manometric measurements of patients with hiatal hernia: A prospective controlled study
}

\section{Hiatal Hernili hastalarda intragastrik manometrik ölçümler: Prospektif kontrollü bir çalışma}

\author{
Kemal Peker ${ }^{1}$, Abdullah İnal $^{1}$, Mustafa Emiroğlu², İsmayil Yılmaz ${ }^{1}$, İsmail Demiryılmaz ${ }^{3}$, Arda Işık $^{1}$
}

\section{ABSTRACT}

Objective: Hiatal hernia is a disorder in which abdominal contents, especially gastroesophageal junction and proximal stomach are displaced through an incompetent esophageal hiatus into mediastinum. Aim of this study is to investigate the relationship betweeen intragastric pressure and incompetent cardioesophageal sphincter and hiatal hernia.

Methods: The sample is composed of 81 individuals; $51.9 \%$ of which are male ( $n: 42$ ) and $48.1 \%$ of which are female ( $n$ : 39 ) with median age of 42.00 . Two groups have been constituted: A control group of healthy volunteers (G1) and a patient group with hiatal hernia (G2). After gastroscopy, all patients and controls underwent gastric and esophageal manometry using a water perfused catheter

Results: Mean intragastric pressure was $1,308 \mathrm{mmHg}$ for $\mathrm{G} 1$ and, $-0,105 \mathrm{mmHg}$ for $\mathrm{G} 2$. Mean lower esophageal pressure were $13,143 \mathrm{mmHg}$ and $11,65 \mathrm{mmHg}$, and upper esophageal pressure were $35,273 \mathrm{mmHg}$ and $27,211 \mathrm{mmHg}$ for $\mathrm{G} 1$ and $\mathrm{G} 2$, respectively. 24 hour $\mathrm{pH}$ metry test revealed $26.8 \%$ physiologic gastroesophageal reflux and $73.2 \%$ pathologic gastroesophageal reflux in G2. There were statistically significant difference between two groups for mean intragastric pressure $(p<0.001)$ and mean lower esophageal pressure $(p<0.05)$.

Conclusion: This study shows that hiatal hernia results in significantly lower intragastric pressures. J Clin Exp Invest 2014; 5 (1): 1-6

Key words: Hiatal Hernia, Manometry, Intragastric Pressures

\section{INTRODUCTION}

The junction between esophagus and stomach is a complex structure which functions to keep gastric content in stomach while preventing the reflux

\section{ÖZET}

Amaç: Hiatus hernisi, diafragmanın özofageal hiatusdaki anatomik zayıflık ya da defekt nedeniyle intraabdominal organların toraksa çıkışı olarak tanımlanabilir. Bu çalışmanın amacı kardio özofageal yetmezlikli ve hiatal hernili hastaların intragastrik basınç düzeylerini incelemekti.

Yöntemler: Çalışmaya 81 hasta dâhil edildi. Hastaların 42 (\%51,9)'si erkek iken 39 (\%48,1)'u bayan idi. Yaş ortalamaları 42 yıl olarak tespit edildi. Hastalardan iki grup oluşturuldu. Bir grup (G1) sağlıklı gönüllü hastalardan oluşur iken, ikinci grup (G2) hiatal herni hali olan hastalardan oluşturuldu. Gastroskopiden sonra, tüm hastalara su perfüzyon sistemli kateter kullanılarak gastrik ve özofageal manometrik ölçümler yapıldı.

Bulgular: Ortalama intragastrik basınç düzeyi kontrol grubu için 1,308 mmHg iken, hasta grubu için bu değer $-0,105 \mathrm{mmHg}$ olarak ölçüldü. Kontrol grubunda distal özofageal gastrik basınç düzeyi 13,143 mmHg iken hasta grubunda bu oran $11,65 \mathrm{mmHg}$ olarak, üst özofageal sfinkter basınç düzeyi sırayla $35,273 \mathrm{mmHg}$ ve 27,211 $\mathrm{mmHg}$ olarak ölçüldü. Hiatal herni hali mevcut olan G2 için yapılan 24 saatlik pH monitörizasyonunda \%26,8 hastada, reflü fizyolojik sınırlarda iken \%73,2 hastada reflü hali patolojik sınırlarda tespit edildi. Gruplar arası intragastrik ve distal özofageal basınç düzeyleri açısından yapılan ikili karşılaştırmalarda sonuçlar istatistiksel olarak anlamlı idi $(p<0.001, p<0.05)$.

Sonuç: Çalışma neticesinde Hiatal Herni halinin intragastrik basınç düzeyini düşürdüğü kanatine varılmıştır.

Anahtar kelimeler: Hiatal herni, manometre, intragastrik basınç

of ingested food into the esophagus through gastroesophageal junction (GEJ) with the coordinated action of lower esophageal sphincter (LES), and its associated structures gastric sling and crural

\footnotetext{
${ }^{1}$ Erzincan University, Department of General Surgery, Erzincan, Turkey

${ }^{2}$ Tepecik Training and Research Hospital, Department of General Surgery, Izmir, Turkey

${ }^{3}$ Ibni Sina Hospital, Department of General Surgery, Kayseri, Turkey
}

Correspondence: Kemal Peker,

Mengücek Gazi Training and Research Hospital, Erzincan, Turkey Email: k.peker@yahoo.com.tr Received: 28.08.2013, Accepted: 21.10.2013

Copyright (C) JCEI / Journal of Clinical and Experimental Investigations 2014, All rights reserved 
diaphragm. The same structure also permits retrograde passage of air and gastric contents into the esophagus during ructus and vomiting. A delicately regulated high pressure zone achieves this precise coordination $[1,2]$. Gastroesophageal reflux disease (GERD) seems to be originated from the imbalance between defensive factors and aggressive factors. GEJ constitutes the first and essential line of esophageal defense against acid damage of refluxate, and impairment in this barrier concludes with pathological reflux [3].

Hiatal hernia $(\mathrm{HH})$ is a disturbance in which parts of abdominal contents, especially GEJ and stomach are displaced proximally through an incompetent esophageal hiatus into mediastinum [4]. Four types of esophageal hiatal hernias have been defined: sliding (type I), paraesophageal (type II), combined (type III), which include elements of types I and II, and giant paraesophageal (type IV). Each type may be presented with different symptoms and complications. Sypmtoms and consequences of the disease necessitates proper and prompt diagnosis [5]. Type I sliding hiatal hernia accounts for more than $95 \%$ of all hiatal hernias while the remaining $5 \%$ represents paraesophageal hiatal hernias [6].

In this study, our purpose is to evaluate relationship between intragastric pressure levels and $\mathrm{HH}$. We also aimed to assess effect of this pathological condition on gastro-esophageal reflux disease.

\section{METHODS}

A prospective controlled clinical study was conducted at Mengücek Gazi Training and Research Hospital in Erzincan, Turkey. This study was approved by the Ethics Committee of the Erzincan University and performed in accordance with Declaration of Helsinki. All patients were asked to provide written informed consent prior to enrollment, after explanation of the associated risks and benefits and description of the study protocol.

The sample is composed of 81 individuals. $51.9 \%$ of participants were male ( $n: 42$ ), and $48.1 \%$ were female (n: 39). Median age of the sample was 42.00 and mean age was 42.29 . All of patients were evaluated by gastroscopy and manometric motility tests. Two groups have been constituted from the sample. First group (G1) was composed of 40 patients whose cardio-esophageal sphincter function was normal. Second group (G2) was composed of 41 patients who had cardio-esophageal sphincter insufficiency and $\mathrm{HH}$. The body mass index (BMI) was calculated as 22,66 for $\mathrm{G} 1$ and 22,91 for $\mathrm{G} 2$. All patients and controls underwent gastric and esophageal manometry using a water perfused catheter with nine radially aligned channels attached to a hydraulic capillary infusion system. Measured intragastric (IG), distal esophageal sphincter (LES) and upper esophageal sphincter (UES) pressure levels were recorded. Additionally, patients in Group 2 (G2) had a 24-hour acidity analysis by $\mathrm{pH}$ meter.

Exclusion criteria for the subjects with normal gastroesophageal function included any abdominal symptoms or any medication that could affect the gastroesophageal segment high-pressure zone, including antacids, $\mathrm{H} 2$ blockers, proton pump inhibitors, prokinetic agents, antibiotics and anticholinergics, GERD, hiatal hernia, conditions and disorders including a history of abdominal pain, heartburn, difficulty in swallowing, pain on swallowing, dysphagia, abdominal surgery involving the stomach or esophagus, nausea or vomiting, diabetes, scleroderma, esophageal motility disorders, noncardiac chest pain, achalasia, and existing pregnancy. Exclusion criteria for hiatal hernia patients were any history of surgery for esophagus or stomach.

\section{Endoscopic evaluation of the study subjects}

All subjects were undergone upper endoscopy after an overnight fast with an Olympus Evis Exera II CRV-180 (Olympus Corp. Tokyo, Japan) endoscope. Subjects were kept in the left lateral decubitus position during the procedure. Benzocaine spray was used to anesthetize the posterior pharyngeal wall since the endoscopy was performed unsedated. Subjects were evaluated for the presence of esophagitis and for any abnormalities in stomach and duodenum, including hiatal hernia.

\section{Manometric evaluation}

All the patients were undergone gastro-esophageal manometry testing. Manometric testing was performed with a 9E-12-100A Menfis Biomedica 9-way catheter (Menfis biomedica s.r.l. Bologna, Italy). The PVC catheter for measurement has external diameter of $12 \mathrm{Fr}(4 \mathrm{~mm})$, operative length of 100 $\mathrm{cm}$, and total length of $180 \mathrm{~cm}$. It has one central lumen of $1.4 \mathrm{~mm}$ diameter, which opens at the tip and four lumina which open with 4 side-ports of 0.8 $\mathrm{mm}$ diameter with radial arrangement at $3 \mathrm{~cm}$ far from the tip. The remaining four lumina open with 4 side-ports, $5 \mathrm{~cm}$ apart along the catheter in helicoidal arrangement. Centimetric markings are starting from the side-port no 8. (Figure 1)

Before the test, device was calibrated on the same level with the patient. Examination was performed with rapid pull-through technique when the 
patient was placed in supine right lateral position. The catheter was pulled by mechanical device with a speed of $1 \mathrm{Sec} / 2,5 \mathrm{~mm}$ under resting condition. (Figure 2).
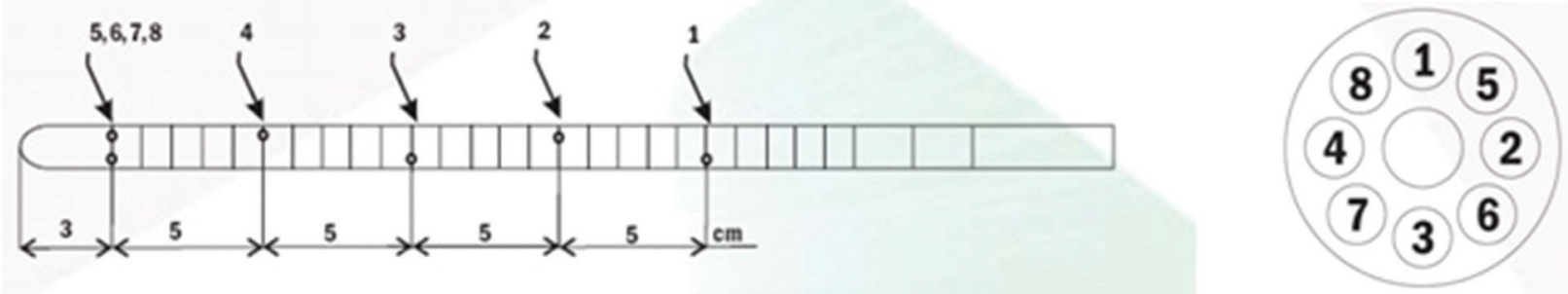

Figure 1. Diagram of gastric manometry catheter which was used in the study

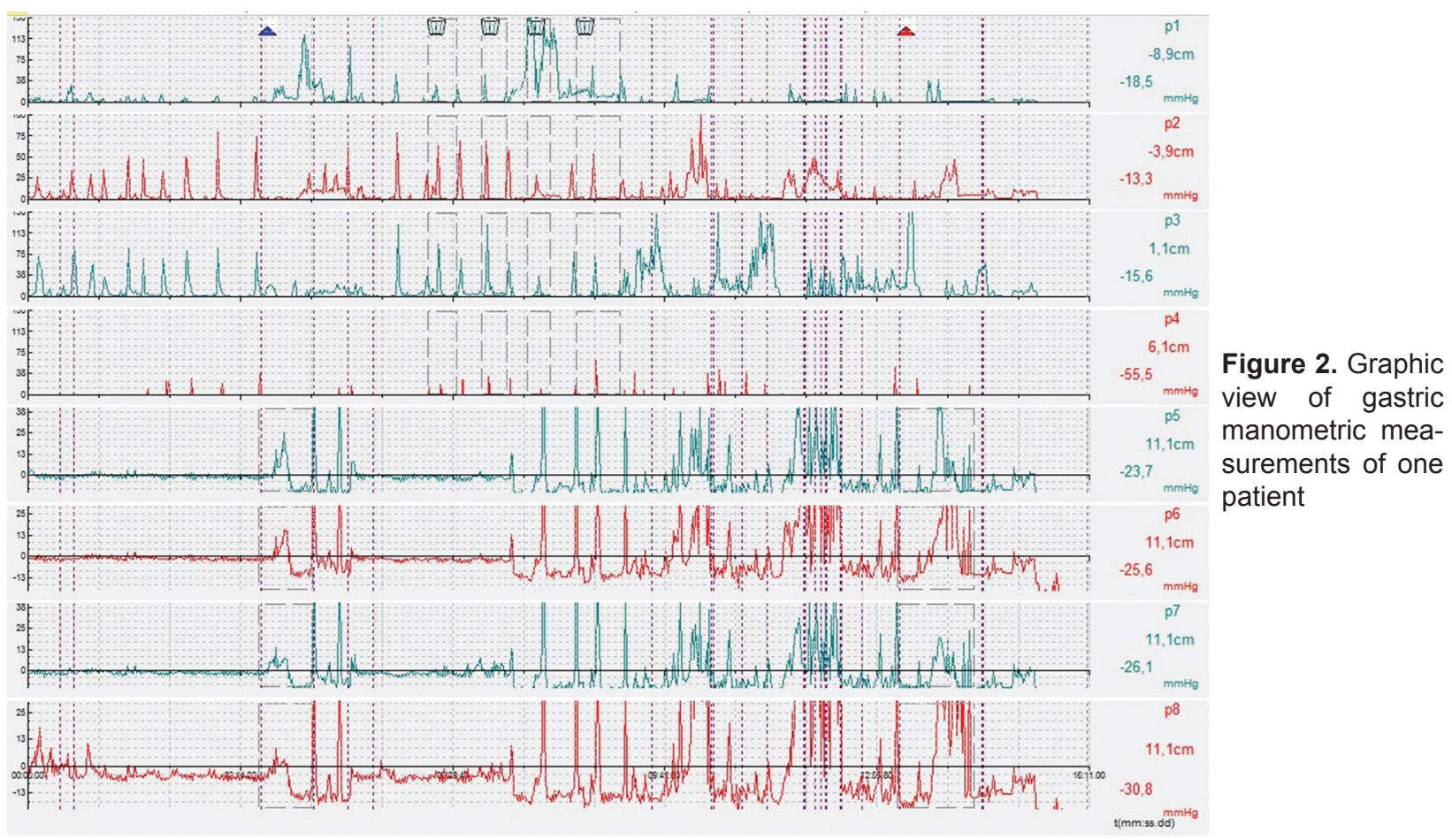

\section{pH-Monitoring}

All the $\mathrm{G} 2$ patients underwent $24 \mathrm{~h}$ distal esophageal $\mathrm{pH}$ monitoring. Proton-pump inhibitor medications were discontinued at least 2 weeks before testing and other reflux medications were discontinued at least $72 \mathrm{~h}$ before testing. The $\mathrm{pH}$ monitoring was performed with an antimony crystal $\mathrm{pH}$ electrode (Menfis Biomedica) $5 \mathrm{~cm}$ above the manometrically measured LES, when patient was placed in supine right lateral position. The electrode was connected to a digital recording device. The stored data were transferred to a computer and analyzed using a standard software package.

\section{Statistical analysis}

Data was analyzed by using SPSS 15.0 software. According to normality tests, the distribution is not normal therefore, non-parameters tests were used. Mann-Whitney $U$ test was used, in order to compare intergroup differences. $P$ value less than 0.05 was accepted as significant.

\section{RESULTS}

Mean IG pressure level was measured $1.308 \pm$ $1.392 \mathrm{mmHg}$ for Group 1 (G1) and $-0.105 \pm 1.651$ $\mathrm{mmHg}$ for Group 2 (G2). Mean LES pressure and mean UES pressure of Group 1 (G1) were measured $13.143 \pm 5.962 \mathrm{mmHg}$ and $35.273 \pm 17.202$ $\mathrm{mmHg}$, respectively. Mean LES pressure and mean UES pressure of Group 2 (G2) were measured $11.65 \pm 7.145 \mathrm{mmHg}$ and $27.211 \pm 10.062 \mathrm{mmHg}$, respectively. As a result of 24-hour $\mathrm{pH}$ meter measurements for Group 2 (G2), there were no gastro- 
esophageal reflux in 11 of patients $(26.8 \%)$, and gastroesophageal reflux condition was defined in 30 of patients $(73.2 \%)$ at pathological levels. Results of mean IG, LES and UES pressure levels are shown on Table 1.

According to test results, the difference between the mean intragastric pressure levels of experiments and control groups was significant ( $p$ $<0.001$ ). Although LES pressure levels were lower in experimental group, there was not a statistically significant difference between LES pressure levels of control and experimental groups $(p=0.0,153)$. However; there was an unexpected significant difference between UES pressure levels of control and experimental groups $(p<0.05)$. The results of the comparison to reflux are shown in Table 2.

The differences are found to be statistically significant between means and mean ranks of IG, LES and UES in patients with and without gastroesophageal reflux disease.
Table 1. Comparison of pressure level in IG, LES and UES between control and patient groups for intragastric pressures

\begin{tabular}{|c|c|c|c|c|c|c|c|c|}
\hline & \multirow{2}{*}{ Group } & \multirow{2}{*}{$\mathrm{n}$} & \multirow{2}{*}{$\bar{X}_{ \pm S D}$} & \multicolumn{3}{|c|}{ Percentiles } & \multirow{2}{*}{$U^{a}$} & \multirow{2}{*}{$\mathrm{p}^{\mathrm{b}}$} \\
\hline & & & & 25. & 50 (Median) & 75. & & \\
\hline \multirow{2}{*}{ IG } & G1 & 40 & $1,308 \pm 1,392$ & 0,39 & 1,27 & 1,80 & \multirow{2}{*}{423,0} & \multirow{2}{*}{$<0,1^{* *}$} \\
\hline & G2 & 41 & $-0,105 \pm 1,651$ & $-0,74$ & 0,40 & 0,94 & & \\
\hline \multirow{2}{*}{ LES } & G1 & 40 & $13,143 \pm 5,962$ & 9,20 & 11,15 & 15,71 & \multirow{2}{*}{669,5} & \multirow{2}{*}{0,153} \\
\hline & G2 & 41 & $11,65 \pm 7,145$ & 6,99 & 10,43 & 14,31 & & \\
\hline \multirow{2}{*}{ UES } & G1 & 40 & $35,273 \pm 17,202$ & 23,23 & 30,53 & 41,88 & \multirow{2}{*}{594,5} & \multirow{2}{*}{$0,027^{*}$} \\
\hline & G2 & 41 & $27,211 \pm 10,062$ & 20,35 & 26,20 & 32,95 & & \\
\hline
\end{tabular}

a. Mann Whitney U Test

b. Monte Carlo Sig.(2-tailed) Based on 10000 sampled table. ${ }^{* *} p<0,001,{ }^{*} p<0,05$

Comparison of pressure level in IG, LES and UES between groups was shown in this table.

Table 2. Comparison of pressure level in IG, LES and UES between groups that were detected reflux and the patients that were not detected reflux was shown in this table.

\begin{tabular}{|c|c|c|c|c|c|c|c|c|}
\hline & & \multirow{2}{*}{$\mathrm{n}$} & \multirow{2}{*}{$\bar{X}_{ \pm S D}$} & \multicolumn{3}{|c|}{ Percentiles } & \multirow{2}{*}{$U^{a}$} & \multirow{2}{*}{$\mathrm{p}^{\mathrm{b}}$} \\
\hline & & & & 25. & 50 (Median) & 75. & & \\
\hline \multirow{2}{*}{ IG } & No reflux & 11 & $-0,538 \pm 1,878$ & $-1,80$ & $-0,23$ & 1,16 & \multirow{2}{*}{139,5} & \multirow{2}{*}{0,472} \\
\hline & Reflux & 30 & $0,053 \pm 1,564$ & $-0,34$ & 0,46 & 0,93 & & \\
\hline \multirow{2}{*}{ LES } & No reflux & 11 & $11,29 \pm 6,975$ & 4,95 & 11,35 & 14,63 & \multirow{2}{*}{161,0} & \multirow{2}{*}{0,913} \\
\hline & Reflux & 30 & $11,782 \pm 7,32$ & 7,02 & 10,10 & 14,19 & & \\
\hline \multirow{2}{*}{ UES } & No reflux & 11 & $30,852 \pm 10,841$ & 23,64 & 27,60 & 36,73 & \multirow{2}{*}{121,5} & \multirow{2}{*}{0,208} \\
\hline & Reflux & 30 & $25,876 \pm 9,604$ & 20,21 & 25,04 & 32,23 & & \\
\hline
\end{tabular}

a. Mann Whitney U Test

b. Monte Carlo Sig.(2-tailed) Based on 10000 sampled table. ${ }^{* * *} p<0,001,{ }^{*} p<0,05$

\section{DISCUSSION}

Since direct measurement of abdominal pressure (IAP) is unfeasible under most circumstances, the homogenous transmission of pressure within the abdomen allows IAP to be estimated via the bladder, rectum or stomach [7]. A number of factors, including patient position, ventilatory state and bowel function influences IAP. Intragastric pressure (IGP) is commonly employed as a substitute measurement for IAP in a number of researchs $[8,9]$.
Intragastric pressure was significantly higher in obese and overweight patients when compared with people with a normal BMI during both expiration and inspiration [10]. The concept of increased gastroesophageal pressure gradient (GEPG) in obese patients was already introduced more than two decades ago. Hypothesis is originated from the assumption that increase in intraperitoneal and abdominal wall fat mass can increase the intraabdominal, and therefore perigastric pressure [11]. Studies of other hollow organs have confirmed the 
presence of increased intra-abdominal pressure in patients with central obesity [12]. Mercer et al. evaluated eight normal weight and eight morbidly obese subjects without clinical evidence of GERD. The authors found no significant difference in mean LES pressure between the two groups during either expiration or inspiration [11]. In contrast, the GEPG was significantly higher in the obese patients in comparison with normal controls both in expiration and inspiration. Consequently, GEPG/LES pressure ratio was also significantly higher in obese patients when compared to normal controls, both in expiration and inspiration [13]. A high BMI increases GEPG mainly by raising IGP [14].

In literature, there are many studies defining the relationship between intragastric pressure level and obesity. Yet, there are not sufficient data defining the relationship between hiatal hernia and intragastric pressure levels. Vegesna et al. [15] determined that IGP levels in $\mathrm{HH}$ are distinctively lower than IGP levels of ordinary patients in manometric studies. Similarly, we found out that IGP levels in hiatal hernia are lower than IGP levels of ordinary patients. The values we obtained in our study were lower than numbers Vegesna et al. determined in their studies. The reason for such difference was that Vegesna et al. performed manometric measurements in the course of endoscopic operation. Conversely, we performed manometric measurements in resting period following endoscopic operation in our study. The results we obtained seem to be more objective.

Hiatus hernia causes a spatial seperation in pressure components of lower esophagus which is derived from the intrinsic lower esophageal sphincter and the extrinsic compression of the esophagus within the hiatal canal, and reduces lower esophageal sphincter pressure and alters its dynamic responsiveness [16]. GERD is very common in the western society; $10-20 \%$ of the population was reported to be suffer from one or more of the cardinal symptoms at least weekly [17]. The main mechanism by which gastroesophageal reflux takes place is the transient relaxation of the lower esophageal sphincter (TLESR) [18]. In patients with HH however, the reflux occurs through other mechanisms [19].

Ott et al. [20] in a study with 319 patients found that rate of acid exposure was $3.7 \%$ in patients without $\mathrm{HH}$ and this rate was found out $5.7 \%$ in patients with $\mathrm{HH}$. They also determined that this rate was 6.6 $\%$ in patients with large $\mathrm{HH}$, and rate was found 4.8 $\%$ in patients with small $\mathrm{HH}$. They found that the re- sults of 24-hour pH meter were normal in 237 (74\%) patients, while the result of 24 -hour $\mathrm{pH}$ meter was abnormal in $82(26 \%)$ patients. Similarly, Ping et al. [21] showed that LES pressure is low in the patients with $\mathrm{HH}$ and patients with $\mathrm{HH}$ were also associated with gastro-esophageal reflux disease more commonly. Lord et al. [22] found that erosive esophagitis rate increased in the patients with $\mathrm{HH}$. Accordingly, we defined 41 patients with hiatal hernia in our study. The results of 24-hour $\mathrm{pH}$ meter were abnormal in $30(73.2 \%)$ patients and reflux was encountered in these patients, as well. The results were normal at $11(26.8 \%)$ patients. Likewise, we found that mean LES pressure was $11,65 \mathrm{mmHg}$ for the patient group and mean LES pressure was lower in comparison with control group. This value was found out to be $13,14 \mathrm{mmHg}$ for the control group. Pressure differences between two groups can be attributed to increased reflux in patients with $\mathrm{HH}$.

In conclusion, IGP and LES pressures reduce in patients with $\mathrm{HH}$. Hiatal hernia may cause disruption in barrier function of GEJ, and therefore change the pressure gradients between body compartments. Disorders of anatomic structures such as LES, crural diaphragm and gastric sling lead to alterations in physiological function. Treatment approaches directed to correct disturbances in normal structure and function may provide improvements in symptoms and normal physiological function.

The study was presented on the $48^{\text {th }}$ Congress of the European Society for Surgical Research, İstanbul- Turkey, 2013.

\section{REFERENCES}

1. Boeckxstaens GE. The lower oesophageal sphincter. Neurogastroenterol Motil 2005; 17: 13-21.

2. Sidhu SA, Triadafilopoulos G. Neuro-regulation of lower esophageal sphincter function as treatment for gastroesophageal reflux disease. World J Gastroenterol 2008;14:985-990.

3. Hyun JJ, Bak YT. Clinical Significance of Hiatal Hernia. Gut and Liver 2011;5:267-277.

4. Marchand $P$. The anatomy of esophageal hiatus of the diaphragm and the pathogenesis of hiatus herniation. J Thorac Surg 1959;37:81-92.

5. Dean C, Etienne D, Carpentier B, et al. Hiatal hernias. Surg Radiol Anat 2012;34:291-299.

6 . Kahrilas PJ. Hiatus hernia causes reflux: fact or fiction? Gullet 1993;3:21-30.

7. Turnbull D, Webber $\mathrm{S}$, Hamnegard $\mathrm{CH}$, et al. İntraabdominal pressure measurement: validation of intragastric pressure as a measure of intra-abdominal pressure. Brit J Anaesth 2007;98:628-623. 
8. Balogh Z, Jones F, D'Amours S, et al. Continuous intraabdominal pressure measurement technique. Am J Surg 2004;188:679-684.

9. Ravishankar N, Hunter J. Measurement of intra-abdominal pressure in intensive care units in the United Kingdom: a national postal questionnaire study. $\mathrm{Br} \mathrm{J}$ Anaesth 2005;94:763-766.

10. Pandolfino JE, El-Serag HB, Zhang Q, et al. Obesity: a challenge to esophagogastric junction integrity. Gastroenterology 2006;130:639-649.

11. Mercer CD, Wren SF, DaCosta LR, et al. Lower esophageal sphincter pressure and gastroesophageal pressure gradients in excessively obese patients. J Med 1987;18:135-146.

12. Sugerman HJ, DeMaria EJ, Felton WL 3rd, et al. Increased intra abdominal pressure and cardiac filling pressures in obesity-associated pseudotumor cerebri. Neurology 1997;49:507-511.

13. Fass R. The Pathophysiological Mechanisms of GERD in the Obese Patient. Dig Dis Sci 2008;53:2300-2306.

14. El Serag HB, Tran T, Richardson P, et al. Anthropometric correlates of intragastric pressure. Scand $\mathrm{J}$ Gastroenterol 2006;41:887-91.

15. Vegesna A, Besetty R, Kalra A, et al. Induced opening of the gastroesophageal junction occurs at a lower gastric pressure in gerd patients and in hiatal hernia subjects than in normal control subjects. Gastroenterol Res Pract 2010;2010:857654.
16. Kahrilas PJ, Lin S, Chen J, et al. The effect of hiatus hernia on gastro-oesophageal junction pressure. Gut 1999;44:476-82.

17. Dent J, El Serag HB, Wallander MA, et al. Epidemiology of gastrooesophageal reflux disease: A systematic review. Gut 2005;54: 710-717.

18. Holloway RH. The anti-reflux barrier and mechanisms of gastro-oesophageal reflux. Best Pract Res Clin Gastroenterol 2000;14:681-699.

19. van Herwaarden MA, Samsom M, Smout AJ. Excess gastroesophageal reflux in patients with hiatus hernia is caused by mechanisms other than transient LES relaxations. Gastroenterology 2000;119:1439-1446.

20. Ott DJ, Glauser SJ, Ledbetter MS, et al. Association of Hiatal Hernia and Gastroesophageal Reflux:Correlation Between Presence and Size of Hiatal Hernia and 24-hour pH Monitoring of the Esophagus.AJR 1995;165:557-559.

21. Ye P, Li ZS, Xu GM, et al. Esophageal motility in patients with sliding hiatal hernia with reflux esophagitis. Chinese Medical Journal 2008;121:898-903.

22. Lord RV, DeMeester SR, Peters JH, et al. Hiatal hernia, lower esophageal sphincter incompetence, and effectiveness of Nissen fundoplication in the spectrum of gastroesophageal reflux disease. J Gastrointest Surg 2009;13:602-610. 